\title{
Health Risk Assessment in Children by Arsenic and Mercury Pollution of Groundwater in a Mining Area in Sonora, Mexico
}

\author{
José Leopoldo Mendoza-Lagunas', Diana María Meza-Figueroa², \\ Marco Antonio Martínez-Cinco ${ }^{3}$, Mary Kay 0'Rourke4, Elena Centeno-García ${ }^{5}$, \\ Francisco Martin Romero5, Leticia García-Rico6, María Mercedes Meza-Montenegro ${ }^{7 *}$ \\ ${ }^{1}$ Programa de Doctorado en Ciencias en Biotecnologia, Instituto Tecnológico de Sonora, \\ Ciudad Obregón, México \\ ${ }^{2}$ División de Ciencias Exactas y Naturales, Departamento de Geología, Universidad de Sonora, Rosales y Encinas, \\ Hermosillo, México \\ ${ }^{3}$ División de Estudios de Posgrado, Facultad de Ingeniería Química, Universidad Michoacana de San Nicolás de Hidalgo \\ (UMSNH), Morelia, México \\ ${ }^{4}$ Mel \& Zuckerman College of Public Health, University of Arizona, Tucson, AZ, USA \\ ${ }^{5}$ Instituto de Geología, Universidad Nacional Autónoma de México, Ciudad Universitaria, Delegación Coyoacán, \\ Ciudad de México, México \\ ${ }^{6}$ Centro de Investigación en Alimentos y Desarrollo, Hermosillo, México \\ ${ }^{7}$ Dirección de Recursos Naturales, InstitutoTecnológico de Sonora, Obregón, México \\ Email: ^mmeza@itson.edu.mx
}

How to cite this paper: Mendoza-Lagunas, J. L., Meza-Figueroa, D. M., Martínez-Cinco, M. A., O’Rourke, M. K., Centeno-García, E., Romero, F. M., García-Rico, L., \& MezaMontenegro, M. M. (2019). Health Risk Assessment in Children by Arsenic and Mercury Pollution of Groundwater in a Mining Area in Sonora, Mexico. Journal of Geoscience and Environment Protection, 7, 90-105.

https://doi.org/10.4236/gep.2019.76008

Received: April 17, 2019

Accepted: June 23, 2019

Published: June 26, 2019

Copyright $\odot 2019$ by author(s) and Scientific Research Publishing Inc. This work is licensed under the Creative Commons Attribution International License (CC BY 4.0).

http://creativecommons.org/licenses/by/4.0/

\begin{abstract}
A highly acidic spill from one of the most important copper mines in the Americas (Buenavista del Cobre) occurred in Sonora, Mexico in August, 2014. $40,000 \mathrm{~m}^{3}$ of metals-enriched sulphate solution escaped into the Sonora River representing the worst ecological disaster in Mexican history. The spill affected the economy, water accessibility and the health of residents near the river. Despite the economic importance of mining in this area, no environmental assessment was undertaken. There is no information about the health impact of this event on the local population. The study assesses the health risk among children exposed to arsenic and mercury via groundwater in five communities located in a mining area into the Sonora River Basin, Mexico. Local drinking water from the localities was sampled one year after the spill and it was analyzed for arsenic and mercury by Atomic Absorption Spectrometry coupled with Hydride Generation (AAS/HG). Further, some of the traditional local foods were sampled and analyzed for the same elements. Results indicate that levels of arsenic in drinking water did not exceed the Mexican Norm $(25 \mu \mathrm{g} \mathrm{As} / \mathrm{L})$ or the EPA Guideline $(10 \mu \mathrm{g} \mathrm{As} / \mathrm{L})$. The concentrations of mercury exceeded the WHO and Mexican Legislation value $(1.0 \mu \mathrm{g}$
\end{abstract}


$\mathrm{Hg} / \mathrm{L}$ ). The Hazard Quotient (HQ) values for arsenic were $>1$ in $42 \%$ of children exposed and for mercury in $67 \%$ of the children. Foods concentrations contained in the ranges of 9.2 to $62.0 \mu \mathrm{g} \mathrm{As} / \mathrm{Kg}$ and 0.28 to $42 \mu \mathrm{g} \mathrm{Hg} / \mathrm{Kg}$ for arsenic and mercury respectively. These values are below the Codex Alimentarius limits. Children affected by mining activities are at risk of developing chronic diseases associated with low arsenic and mercury exposure via groundwater consumption, without consideration of the contribution from these metals by other important exposures routes.

\section{Keywords}

Hazard Quotient, Mining, Mercury, Arsenic, Children

\section{Introduction}

Mining is an important economic activity in many countries, and a major source of pollution in groundwater (Malm, 1998). Wastes, as metals, are produced by these mines and represent a pollutant source for superficial water and deep wells (Higueras et al., 2004). Mining activities generally are far from big cities. However, small towns grow where mines are located as workers move to the site and then experience ecological damage e.g. deforestation and groundwater pollution caused by the mining activity (Zulling \& Hendryx, 2011).

The presence of metals affects the groundwater quality (Polanco et al., 2017; Buschmann et al., 2007), and is due to contact with the ore and human activity (Steckling et al., 2017). Water sources of some communities located near an iron mine in Liberia, Africa, contained higher levels of arsenic, mercury, and selenium than the Maximum Contaminant Levels established by the World Health Organization (WHO) (Gleekia et al., 2016).

Through history, events related to mining operations had important negative environmental effects. For example, in April, 1998, a mining spill of acid waste occurred at the Aznalcóllar mine, in Spain, negatively affecting the Guadalquivir estuary (Gomez-Parra et al., 2000). More recently in Cajacay, Perú, a broken pipe spilled zinc and copper poisoning 111 people including a significant number of children (Robles et al., 2012). In September 2015, in San Jose, Argentina, a gold mine spilled 1,000,000 liters of cyanate solution, affecting at least 5 rivers (MCH, 2016). In Mariana, Brazil, in October, 2015, two mine reservoirs collapsed, releasing $62,000,000 \mathrm{~m}^{3}$ of mud containing toxic metals. The spill reached the Atlantic Ocean, through the Dulce River and altered the biodiversity of rivers and coasts (Fato, 2015). The use of mercury in artisanal gold mining contaminates adjacent surface water at levels from 15 to $32 \mu \mathrm{g} \mathrm{Hg} / \mathrm{L}$ (Mahamady \& Orhan, 2016).

Mining activity negatively affects human health as a result of ecosystem damage. Recent reports demonstrate that people who lived near a gold mine in Ecuador presented unacceptably high mercury levels in their urine (Schutzmeier et al., 2016). Mining activities impact primary food production around the world. 
The National Human Exposure Assessment Survey (NHEXAS) of Arizona found that communities near mines were exposed to arsenic from water, dust and food resulting in elevated urinary biomarkers (O'Rourke et al., 1999). Research made in Hunan Province, China, found that soybean crops were affected by heavy metals from the soil because of surrounding mining activity (Zhou et al., 2013). Similarly in Karnataka, India, the concentration of arsenic in food grains cultivated in soil near of gold mines was greater than other grains grown in soil far from mines (Chakraborti et al., 2013). Rice grown in soil at an abandoned mine contained arsenic in the range of $104-774 \mu \mathrm{g} / \mathrm{Kg}$ at a site in Korea (Kwon et al., 2017).

Arsenic and mercury are some of the most toxic metals generated by mining activities and drinking water consumption is one of the most important exposure routes for humans. Children are considered the group most vulnerable to a variety of contaminants and they are more susceptible to environmental exposure compared with adults (Trejo-Acevedo et al., 2009). Arsenic is notorious for its toxicity. Chronic exposition to high arsenic levels through drinking water can cause cancer of the skin, bladder, kidneys, and lungs, arterial hypertension, cardiovascular diseases, neuropathies, lung diseases, and even diabetes (Chen et al., 1992; Smith et al., 1998; Chun et al., 2000; Burgess et al., 2013). Even low chronic exposure to arsenic through drinking water $(10-50 \mu \mathrm{g} / \mathrm{l})$ can produce these diseases in humans (Argos et al., 2010; Sohel et al., 2009). Mercury is also an important neurotoxic agent (Sly \& Proncenzuk, 2007) that can severely affect fetal and postnatal development (Grandjean, 2007; Murata et al., 2004). Mercury can cause irreversible damage to the nervous system; producing neurological developmental delay. Mercury causes arterial hypertension and arrhythmias in low doses, and mental developmental delay at high doses in children (Grandjean et al., 2004; Thurston et al., 2007; Eke \& Celik, 2008).

Sonora is located in the northwest of Mexico, on the Mexico-US border; the Sierra Madre Occidental run from N to S across the State. Gold, silver, copper, molybdenum, and others metals are found in the mountains (SGM, 2014). Buenavista del Cobre is one of the most important copper mines and is located in Cananea, Sonora, $35 \mathrm{~km}$ south of the USA border. This mine is one of the largest copper reserves in the world (Del Águila et al., 2017). The Sierra Madre is part of the basin and range physiographic province; basins include the Bacanuchi and Bacoachi rivers whose confluence at Arizpe becomes the Sonora River (Figure 1), and flows downstream through the communities of Aconchi, Baviacora, and Ures (Figure 1).

The area has been studied geologically, but as of yet there is very little information about the health impact caused by the mining activity on the population and no information about the risk posed by failure of the retaining dam in 2014, where $40,000 \mathrm{~m}^{3}$ of copper sulphate and sulphuric acid enriched with metals spilled from Buenavista del Cobre mine, reaching the Bacanuchi river (Figure 1), impacting $254 \mathrm{~km}$ of the extension of the Sonora River and approximately 322 water wells. The impacted area has 23,261 habitants, of which about $19 \%$ are 

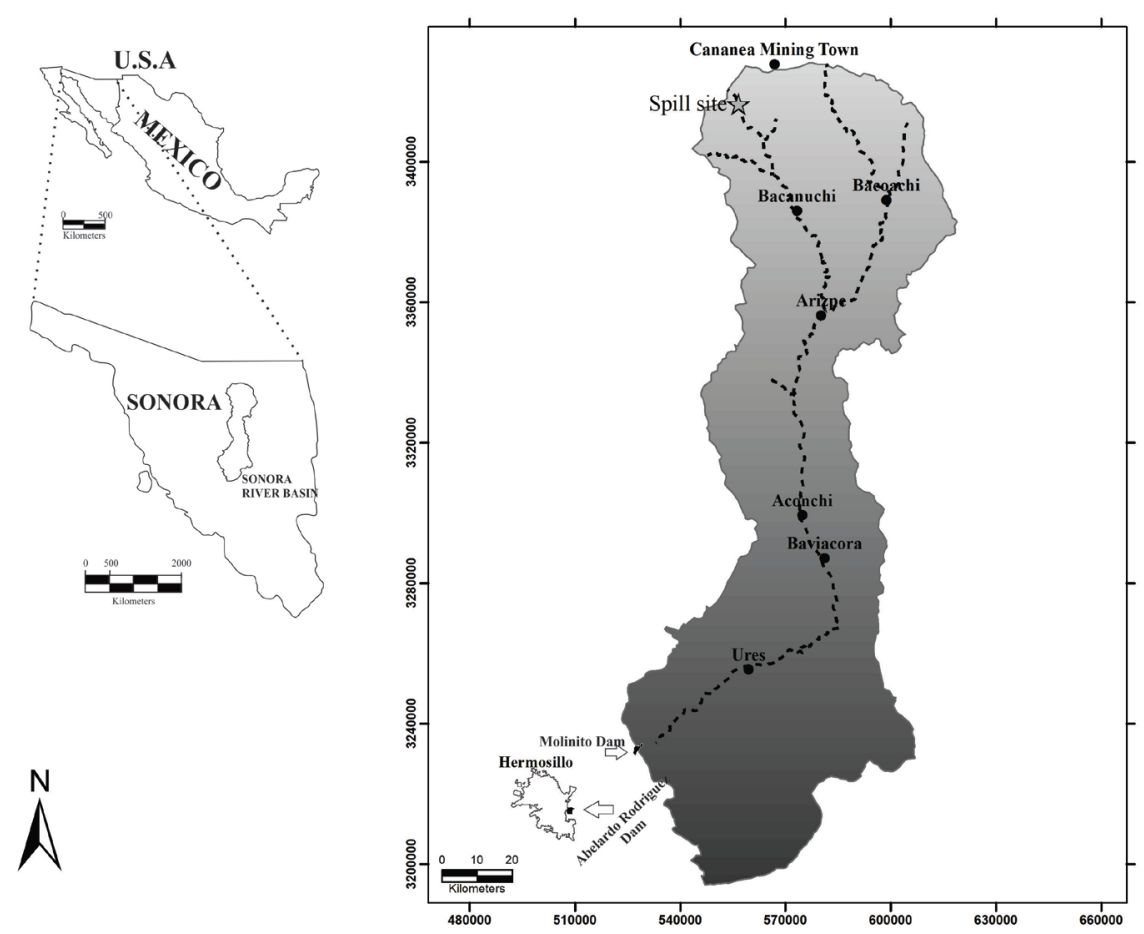

Figure 1. Sonora River geographical location.

children under 14 years of age, according to data from the National Institute of Statistics and Geography (INEGI). Local wells draw from the river and are the major source of drinking water for the communities located along the Sonora River Basin serving both people and agriculture. The Sonora River basin is considered a tourist destination because of its gastronomy and natural landscape. The spill occurred in 2014, causing distrust of traditional local foods and hence impacting the economy of the communities located along the Sonora River Basin.

The spill from the Buenavista del Cobre mine is the worst ecological disaster in Mexican history (SEMARNAT, 2014). The Mexican Federal Government initiated the "Escrow Account for the Sonora River", which involved collaborative actions between various government institutions, (e.g. Environmental Ministry and Natural Resources, SEMARNAT,) universities and private institutions (Grupo Mexico, S.A de C.V) to evaluate the ecological and biological impact of this environmental disaster and propose bioremediation strategies. The website of the initiative reported a mean arsenic concentration of $27.5 \pm 0.005 \mu \mathrm{g} \mathrm{As} / \mathrm{lin}$ 13 sampling sites of surface water upstream from the Molinito dam which controls the water flow of Sonora River Basin (Figure 1), while mercury was reported as non-detectable. On the other hand, the Mexican Geological Survey (SGM) in 2014, reported concentrations of arsenic between 2 and $14 \mathrm{mg} / \mathrm{Kg}$ in the stream sediment in the study towns (except in Baviácora where measurements were not taken.) But so far, there is no information about arsenic and mercury levels in the groundwater from these small communities. This is the first study which assessed the health risk in children exposed to arsenic and 
mercury via drinking water in this mining area following the copper mine acid spill on the Sonora River Basin.

\section{Materials and Methods}

\subsection{Study Area}

The Sonora River basin is characterized by its diversity, both of vegetation and geological features. According to the National Water Commission (CNA), the river is an intermittent stream since the rainfall is relatively low $(85-115 \mathrm{~mm}$ in high areas and $25-50 \mathrm{~mm}$ in low areas). Because of the high temperatures, between $38^{\circ} \mathrm{C}$ and $41^{\circ} \mathrm{C}$ during the monsoon, and the geographical location, there is riparian habitat surrounded by xerophytic scrub in the north and east and oak grasslands, and scrub in the north (INEGI, 2010). Based on active exploitative activities, mining searches and population demographics, the towns of Bacanuchi, Arizpe, Aconchi, Baviácora, and Ures were selected for this study (Figure $1)$.

\subsection{Drinking Water and Food Collection}

Tap water samples were taken randomly from 10 households in each town (Bacanuchi, Arizpe, Aconchi, Baviácora, and Ures), in $500 \mathrm{ml}$ polypropylene containers. Each sample was preserved with nitric acid $\left(\mathrm{HNO}_{3}\right)$, and refrigerated until its laboratory analysis. Drinking water available in the region is obtained from wells. The most common local traditional foods were sampled in each village (flour tortilla, empanada, chiltepin sauce, cheese). These were purchased and immediately stored in coolers with ice and salt for transport.

\subsection{Ethical Issues}

Informed consent forms were signed by both the tutor and the participant. Interview questions and all data obtained were managed according to guidelines of the Institutional Bioethics Committee of Instituto Tecnológico de Sonora (ITSON).

\subsection{Recruitment and Data Collection}

At least 20 preschoolers ( 2 - 6 years old) were recruited at home for each town studied. The interviews were completed in the presence of the child's tutor. Age, weight, height, and daily water intake data were collected to calculate the hazard quotient (HQ).

\subsection{Drinking Water Analysis}

Both arsenic and mercury were measured and compared to regulatory Standards (Mexican Norm; NMX-AA-051-SCFI-2001). To quantify total arsenic in the water, $50 \mathrm{ml}$ of each sample were placed in a $100 \mathrm{ml}$ volumetric flask, and $4 \mathrm{ml}$ $20 \%$ potassium iodine $(\mathrm{KI})$ and $8 \mathrm{ml}$ of $50 \%$ hydrochloric acid $(\mathrm{HCl})$ were added, and then enough distilled water to reach $100 \mathrm{ml}$. The content was transferred 
to a polypropylene container, and it was heated to between $60^{\circ} \mathrm{C}-80^{\circ} \mathrm{C}$ for 5 minutes, and returned to room temperature. For the arsenic analysis the air/acetylene flame was used and the arsenic lamp was adjusted at $193.7 \mathrm{~nm}$. Sodium borohydride $\left(\mathrm{NaBH}_{4}\right)$ was used as a reductant agent.

For the mercury quantification, $50 \mathrm{ml}$ of sample were also poured into a 100 $\mathrm{ml}$ volumetric flask, $1 \mathrm{ml}$ of $1 \%$ potassium dichromate $\left(\mathrm{K}_{2} \mathrm{Cr}_{2} \mathrm{O}_{7}\right)$ and distilled water to $100 \mathrm{ml}$ were added, and chloride $\left(\mathrm{SnCl}_{2}\right)$ was used as reductant agent. Mercury was detected using the cold steam method at $253.7 \mathrm{~nm}$, and for both analyses argon was used as a transport gas. For arsenic and mercury quantifications calibrations curves were prepared using five arsenic and mercury standards levels $(5,10,20,30$ and $40 \mathrm{ppb})$ respectively. For the arsenic and mercury determination, an Atomic Absorption Spectrophotometer (Agilent Technologies 220 Series AA) coupled to a vapor generator (VGA77 Agilent Technologies) was used. As a quality control, $30 \%$ of the drinking water and food samples were spiked with $10 \mathrm{ppb}$ of arsenic and mercury to determine quality parameters.

\subsection{Food Analysis}

Arsenic and mercury in food were quantified according with the Mexican norms (NOM-117-SSA1-1994), with a slight modification, briefly, $1.25 \mathrm{~g}$ and $2.5 \mathrm{~g}$ of the dry and wet samples respectively, were weighed and settled in a beaker and $15 \mathrm{ml}$ of the tri-acid solution $\left(1 \mathrm{HNO}_{3}: 1 \mathrm{HCl}: 1 \mathrm{HClO}_{4}\right)$ were quickly added, and heated for its digestion. Once a crystalline liquid was obtained, the fluid was filtered through Whatman No. 42 into a $100 \mathrm{ml}$ volumetric flask, and analyzed for arsenic and mercury.

The percentages of recovery for arsenic and mercury showed values of $106.1 \%$ and $92.7 \%$ respectively. The coefficient of variation $(\mathrm{CV})$ was equal to or lower than $6.6 \%$, and the detection limits were of 0.9 and $0.8 \mu \mathrm{g} / \mathrm{L}$ for arsenic and mercury respectively. According to the AOAC International guidelines for metals, the recovery obtained was within the expected parameters $(80 \%-115 \%)$ and also the $\mathrm{CV}$ percentages. In addition the calibration curve showed a regression coefficient of $\left(\mathrm{R}^{2}\right)>0.99$.

\subsection{Risk Assessment}

The non-carcinogenic risk assessment (Hazard Quotient; HQ) was calculated for arsenic and mercury, according to the US-EPA formula (USEPA, 2008).

$$
\begin{gathered}
\mathrm{ADD}=\frac{\mathrm{C} * \mathrm{IR} * \mathrm{EF} * \mathrm{ED}}{\mathrm{AT} * \mathrm{BW}} \\
\mathrm{HQ}=\frac{\mathrm{ADD}}{\mathrm{RfD}}
\end{gathered}
$$

were $\mathrm{C}$ is the metal concentration $(\mathrm{mg} / \mathrm{L})$ in ground water, IR is rate water intake (L/day), ED is the exposure duration (in years), EF is the exposure frequency (365 days/year), and the averaging time (AT) is the ED multiplied by the average time (365 days) (USEPA, 2013). In this study, ED and ED and body weight 
(BW) expressed in kg, were taken from the survey of each participant.

\subsection{Statistical Analysis}

A one way ANOVA was used to determine difference in concentration among towns, and all ANOVA assumptions were verified. A chi square test was used to validate percentages of $\mathrm{HQ}$ greater than one per town. Confidence intervals for proportions, ANOVA, Square Chi test and basic statistics were performed in Minitab $17^{\circledR}$.

\subsection{Results and Discussion}

Table 1 shows the average age value for the total children $(\mathrm{n}=123), 3.5 \pm 1.24$ years old, and there was not statistical difference in age by town $(p>0.05)$. According to the Human Growth Charts from the Center for Disease Control and Prevention (CDC, 2000), most of the children in the towns had appropriate height for age and weight for height proportions, i.e. between the $5^{\text {th }}$ and $95^{\text {th }}$ percentile. It should be noted children who lived in Ures were in the highest weight/height percentile (94.4), of the study towns, Ures is the biggest and is located nearest to a big city, Hermosillo, giving the children greater diversity of food accessibility.

Table 2 shows the average \pm SD levels of the arsenic and mercury in drinking

Table 1. Population distribution by age and nutritional description.

\begin{tabular}{ccccccc}
\hline Town & $\mathbf{N}$ & *Age \pm SD & Girls \% & Boys \% & $\begin{array}{c}\text { Percentile } \\
\text { Height/Age }\end{array}$ & $\begin{array}{c}\text { Percentile } \\
\text { Weight/Height }\end{array}$ \\
\hline Bacanuchi & $\mathrm{n}=20$ & $3.5 \pm 1.3$ & 58.3 & 41.7 & 94.9 & 89.1 \\
Arizpe & $\mathrm{n}=24$ & $3.5 \pm 1.3$ & 50.0 & 50.0 & 87.8 & 67.9 \\
Aconchi & $\mathrm{n}=25$ & $3.1 \pm 1.2$ & 52.0 & 48.0 & 61.6 & 72.8 \\
Baviácora & $\mathrm{n}=22$ & $3.6 \pm 1.1$ & 40.9 & 59.1 & 88.2 & 77.5 \\
Ures & $\mathrm{n}=26$ & $3.8 \pm 1.2$ & 69.3 & 30.7 & 94.4 & 94.4 \\
Total & $\mathrm{n}=123$ & $3.5 \pm 1.2$ & 54.4 & 45.5 & 90.1 & 72.8 \\
\hline
\end{tabular}

*For age is shown the average and de Standard Deviation (SD).

Table 2. Arsenic and mercury concentrations in the drinking water from the wells located in the towns of the Sonora River Basin.

\begin{tabular}{cccc}
\hline $\begin{array}{c}\text { Town } \\
(\mathrm{n})\end{array}$ & $\begin{array}{c}\text { Size of sample } \\
(\mathrm{n})\end{array}$ & $\begin{array}{c}\text { Mean arsenic } \\
(\mu \mathrm{g} / \mathrm{l} \pm \mathrm{SD})\end{array}$ & $\begin{array}{c}\text { Mean mercury } \\
(\mu \mathrm{g} / \mathrm{l} \pm \mathrm{SD})\end{array}$ \\
\hline Bacanuchi & 9 & $3.6 \pm 5.5$ & $2.2 \pm 0.2$ \\
Arizpe & 10 & $3.1 \pm 0.8^{*}$ & $2.6 \pm 1.9$ \\
Aconchi & 10 & $5.1 \pm 1.3$ & $2.1 \pm 0.3$ \\
Baviácora & 10 & $5.8 \pm 3.7$ & $2.0 \pm 0.08$ \\
Ures & 10 & $5.6 \pm 3.9$ & $1.9 \pm 0.1$ \\
\hline
\end{tabular}

${ }^{\star}$ Means different from the other towns $(p<0.005)$. 
water from Ures, Baviácora, Aconchi, Arizpe, and Bacanuchi (where $\mathrm{n}=10$ except for Bacanuchi where $n=9$ ). None of the obtained concentrations for arsenic in the drinking water samples exceeded the Mexican guideline established for arsenic in tap water limited to $25 \mu \mathrm{g}$ As/l (Norma Oficial Mexicana, NOM-127-SSA1-1994) or the World Health Organization (WHO), with a recommended value of $10 \mu \mathrm{g} \cdot \mathrm{As} / \mathrm{l}$. However $1 \%$ of the individual samples from Ures, Baviácora and Bacanuchi had values above of the WHO norm with values of $14.5,15.9$ and $17.8 \mu \mathrm{g}$. As/l respectively. For mercury, the average concentrations were in the range of $1.9 \pm 0.1$ to $2.6 \pm 1.9 \mu \mathrm{g} \cdot \mathrm{Hg} / \mathrm{l}$ (Table 2), levels which exceeded the established value for the Mexican norm $(1.0 \mu \mathrm{g} \cdot \mathrm{Hg} / \mathrm{l})$.

The contamination of the water caused by the mining industry is documented around the world. In southern Armenia, heavy metals were studied in the surface water of minor rivers of the Voghchi and Meghri basins near a mining zone. They found arsenic concentrations between 1.2 to $3.6 \mu \mathrm{g}$. As/l, values within the range found in our study (Babayan et al., 2017). A study carried out in Kilembe, Armenia, reported that the ore processing and the center leachate were responsible for increasing arsenic contamination in the Nyamwamba River from levels of $0.12 \pm 0.1$ to $1.5 \pm 4.2 \mu \mathrm{g} / \mathrm{l}$, concentrations lower than we found in our study towns (Mwesigye \& Tumwebaze, 2017).

In Mexico, in a mining zone near Zacatecas, values of arsenic in drinking water exceeded the Mexican guideline by 50 times (Razo et al., 2004). These were the highest values that we found in the reviewed literature including data from our own study.

Yasuda et al. (2011) carried out a study in Indonesia in a gold mining area close to Cikaniki River, finding mercury concentrations in the range of 0.83 to $1.07 \mu \mathrm{g} / \mathrm{l}$, levels lower than we detected in our communities affected by the copper mine acid spill. In a study carried out by Adjei-Kyereme et al. (2015) in the Asutifi District, Ghana, was reported mining activity increases the concentration of mercury from $<1$ to $5.3 \pm 3.7 \mu \mathrm{g} / \mathrm{l}$, especially in the dry season. It is important to mention that despite the geographical differences in the reported studies and this research, the presence of mercury in water as a consequence of the mining activity was common among all the studies.

According to data published on the website of "Escrow Account for the Sonora River", mercury reached its highest concentration in surface water $(1.86 \mu \mathrm{g} / \mathrm{l})$ 20 days after the spill happened. The rest of the $\mathrm{Hg}$ values showed across the study time varied to 0.3 to $0.5 \mu \mathrm{g} / \mathrm{l}$. The official website, however, shows only mercury concentrations in the river flow, and does not mention metal concentrations in the wells. The 2014 spill is not the only one but is the most documented by a variety of communication media and scientific studies this later not published yet. The presence of mercury in the drinking water from our study area is also supported by reports which show that artisanal gold mining activity is done near these towns, as mercury is used for gold purification (Zulling \& Hendryx, 2011). González-Merizalde et al. (2016) reported the presence of mercury in several rivers of the Nangaritza River basin in the Ecuadorian Amazon 
mining area with levels $<1 \mu \mathrm{g} \cdot \mathrm{Hg} / \mathrm{l}$ (González-Merizalde et al., 2016), values lower than we found in our study area.

Table 3 shows the ADD and HQ values for arsenic and mercury. Even though, the average value $(n=117)$ of arsenic concentrations did not exceed the WHO recommendations, we found that at least one third of the children are at risk $(H Q>1)$. Children from Ures and Baviácora had percentages of HQ $>1$ of $57 \%$ and $77 \%$ respectively. According to HQ values from the total population between $34 \%$ and $53 \%$ of the children are at risk to develop some chronic disease induced by arsenic. Martinez-Acuña et al. (2016) carried out a study in Zacatecas, Mexico, and showed at least $74 \%$ of the children from seven communities near a mining zone had HQ values higher than 1 for arsenic exposure, with a mean value of ADD 1.2E-3. Another study carried out in the mining area in Cambodia, reported that children exposed to arsenic had values of HQ between 10.02 and 12.18 , with $\mathrm{ADD}$ values of $3.6 \mathrm{E}-2$ and $3.0 \mathrm{E}-2$ for female and male respectively (Phan et al., 2010), the HQ results from our study population were lower than those findings, since the arsenic levels in drinking water and the ADD values were smaller. However, it should be noted that extreme summer temperatures in these towns may have increased water consumption since a third of the children had values of $\mathrm{HQ}>1$, or they had arsenic contribution by other sources like foods and/or artisanal mining.

For the total population $(\mathrm{n}=117)$ the HQ values for mercury demonstrated that more than $67 \%$ of the children are at risk of developing some chronic disease by mercury exposure. When considering the ADD values, children from Bacanuchi ingested more mercury than children from the other communities

Table 3. Arsenic and Mercury Hazard Quotient and Average Daily Dose per town.

\begin{tabular}{|c|c|c|c|c|c|}
\hline Element & Town (n) & $\begin{array}{c}\mathrm{ADD} \\
\mathrm{mg} / \mathrm{Kg} / \text { day }\end{array}$ & $\begin{array}{l}\text { HQ (mean } \\
\min -\max \text { ) }\end{array}$ & $\begin{array}{c}\% H Q>1 \\
\text { above }\end{array}$ & $\begin{array}{c}\text { Confidence Interval } \\
\qquad(\alpha=0.95)\end{array}$ \\
\hline \multirow{6}{*}{ Arsenic } & Bacanuchi (20) & $1.91 \mathrm{E}-05$ & $1.3(0.3-2.8)$ & 45 & $23-68.4$ \\
\hline & Arizpe (24) & $6.25 \mathrm{E}-06^{*}$ & $0.4(0.1-0.7)$ & 0 & ---- \\
\hline & Aconchi (25) & $1.33 \mathrm{E}-05$ & $1.0(0.2-4.0)$ & 34 & $21.1-61.3$ \\
\hline & Baviácora (22) & $1.98 \mathrm{E}-05$ & $1.3(0.4-2.9)$ & 77 & $56.4-92.1$ \\
\hline & Ures (26) & $1.63 \mathrm{E}-05$ & $1.1(0.3-2.9)$ & 57 & $36.9-76.6$ \\
\hline & Total (117) & $1.47 \mathrm{E}-05$ & $1.0(0.1-4.0)$ & 42 & $34.4-53$ \\
\hline \multirow{6}{*}{ Mercury } & Bacanuchi (20) & $1.34 \mathrm{E}-05^{\star}$ & $2.7(0.7-5.9)$ & 80 & $56.3-94.2$ \\
\hline & Arizpe (24) & $5.27 \mathrm{E}-06$ & $1.0(0.3-1.7)$ & 58 & $36.6-77.8$ \\
\hline & Aconchi (25) & $5.71 \mathrm{E}-06$ & $1.3(0.3-5.1)$ & 64 & $42.5-82$ \\
\hline & Baviácora (22) & $6.77 \mathrm{E}-06$ & $1.3(0.4-3.0)$ & 77 & $54.6-92.1$ \\
\hline & Ures (26) & $5.63 \mathrm{E}-06$ & $1.1(0.3-3.0)$ & 57 & $36.9-76.6$ \\
\hline & Total (117) & $7.06 \mathrm{E}-06$ & $1.4(0.3-5.9)$ & 67 & $57.3-75.1$ \\
\hline
\end{tabular}

${ }^{*}$ Means different from the other towns $\mathrm{p}<0.05$. Hazard Quotient (HQ); Average Daily Dosse (ADD); Reference dose for arsenic 3.0E-4 $\mu \mathrm{gKg}^{-1} \mathrm{dí}^{-1}$ reference dose for mercury $1.0 \mathrm{E}-4 \mu \mathrm{gKg}^{-1} \mathrm{dí}^{-1}$ (US-EPA, 1992). 
with a mean value of $1.34 \mathrm{E}-05$, which is significantly greater when compared with the other towns $(\mathrm{p}<0.05)$ where $80 \%$ of the children had HQ values higher than 1 .

Table 4 shows the HQ values obtained in our study, compared with others populations exposed to arsenic and mercury through drinking water and foods. Oribi et al. (2010), carried out a study in Ghana, reporting that young residents from a mining community exposed to mercury through drinking water had a value of $\mathrm{HQ}=2.1$, our study had a value of $\mathrm{HQ}=1.4$, both results higher than 1 . Recent investigations report the consumption of fish as the major exposure route for organic mercury, which is very neurotoxic. Castilhos et al. (2015) reported residents from Brazil living near a gold mine had a value of $\mathrm{HQ}=5.8$ due primarily to consumption of polluted fishes. De Miguel et al. (2014), reported high values of $\mathrm{HQ}=4.5$ for adults from Antioquia, Colombia, as a result of the consumption of fish coming from a polluted river near a gold mine.

Despite the fact that we measured only the exposure pathway from water, both from drinking and cooking, we still found values of HQ $>1$. These values would potentially be higher with the contribution from others routes like foods and soils.

Table 5 shows the arsenic and mercury concentrations in some local commercial foods from these communities. None of analyzed food exceeded the Codex Alimentarius limits of 250 and $100 \mu \mathrm{g} / \mathrm{Kg}$ for arsenic and mercury respectively. Since local foods represent the usual diet of our population, other

Table 4. Comparison of our results with other reports in the world.

\begin{tabular}{|c|c|c|c|c|c|c|c|}
\hline Author & Place & Subjects & Matrix & Metal & {$[\mu \mathrm{g} / 1]$} & ADD & HQ \\
\hline \multirow[t]{10}{*}{ Our Study } & \multirow[t]{2}{*}{ Bacanuchi } & \multirow[t]{2}{*}{ Children } & \multirow[t]{2}{*}{ Groundwater } & As & 3.6 & $1.91 \mathrm{E}-05$ & 1.3 \\
\hline & & & & $\mathrm{Hg}$ & 2.2 & $1.34 \mathrm{E}-05$ & 2.7 \\
\hline & \multirow[t]{2}{*}{ Arizpe } & & & As & 3.1 & $6.25 \mathrm{E}-06$ & 0.4 \\
\hline & & & & $\mathrm{Hg}$ & 2.6 & $5.27 \mathrm{E}-06$ & 1.0 \\
\hline & \multirow[t]{2}{*}{ Aconchi } & & & As & 5.1 & $1.33 \mathrm{E}-06$ & 4.0 \\
\hline & & & & $\mathrm{Hg}$ & 2.1 & $5.71 \mathrm{E}-05$ & 1.3 \\
\hline & \multirow[t]{2}{*}{ Baviácora } & & & As & 5.8 & $1.98 \mathrm{E}-05$ & 1.3 \\
\hline & & & & $\mathrm{Hg}$ & 2.0 & $6.77 \mathrm{E}-06$ & 1.3 \\
\hline & \multirow[t]{2}{*}{ Ures } & & & As & 5.6 & $1.63 \mathrm{E}-05$ & 1.1 \\
\hline & & & & $\mathrm{Hg}$ & 1.9 & $5.63 \mathrm{E}-06$ & 1.1 \\
\hline Phan et al., 2010 & Kandal, Cambodia & Female children & Groundwater & As & 846.14 & $3.0 \mathrm{E}-3$ & 10.02 \\
\hline $\begin{array}{l}\text { Martinez-Acuña et al., } \\
2016\end{array}$ & $\begin{array}{c}\text { Guadalupe, } \\
\text { Zacatecas, México }\end{array}$ & Children & Tap water & As & 78 & $2.0 \mathrm{E}-3$ & 6.7 \\
\hline \multirow{2}{*}{ Qian et al., 2010} & \multirow{2}{*}{ China } & \multirow{2}{*}{ Children $(4-7$ y/o) } & \multirow{2}{*}{ Milled rice } & As & 119 & $8.8 \mathrm{E}-1$ & \multirow{2}{*}{$\mathrm{N} / \mathrm{R}$} \\
\hline & & & & $\mathrm{Hg}$ & 5.8 & $4.5 \mathrm{E}-2$ & \\
\hline Muhammad et al., 2010 & Jalil-Dubair, Pakistan & Adults & Groundwater & As & 6.07 & $1.7 \mathrm{E}-4$ & 0.56 \\
\hline \multirow{2}{*}{ Wongsasuluk et al., 2014} & \multirow{2}{*}{ Muahng, Thailand } & \multirow{2}{*}{ Adults } & \multirow{2}{*}{ Groundwater } & As & 1.06 & \multirow{2}{*}{$\mathrm{N} / \mathrm{R}$} & 0.28 \\
\hline & & & & $\mathrm{Hg}$ & 0.10 & & $1.8 \mathrm{E}-3$ \\
\hline Jin-Soo et al., 2005 & Songcheon, Korea & Adults & Stream waters & As & 246 & $3.1 \mathrm{E}-3$ & 10.3 \\
\hline Oribi et al., 2010 & Obuasi, Ghana & Children $(2-19$ y/o $)$ & Drinking water & $\mathrm{Hg}$ & 0.89 & $3.4 \mathrm{E}-4$ & 2.1 \\
\hline
\end{tabular}

y/o: years old; N/R: no reported. 
Table 5. Concentrations of Arsenic and Mercury in "artisanal or local commercial foods" from the communities of the Sonora River Basin.

\begin{tabular}{cccc}
\hline Local of food & Town & As $(\mu \mathrm{g} / \mathrm{Kg})$ & $\mathrm{Hg}(\mu \mathrm{g} / \mathrm{Kg})$ \\
\hline Coyota (wheat cookie) & Ures & 17.99 & 24.51 \\
Corico (corn cookie) & Ures & 36.11 & 11.69 \\
Flour tortilla & Ures & 30.00 & 11.83 \\
Jamoncillo (milk candy) & Ures & 23.69 & 13.1 \\
Traditional bread & Ures & 36.85 & 14.93 \\
Pumpkin empanada (sweet bread & Ures & 48.48 & 15.07 \\
Cooked cheese with chile & Ures & 33.36 & 0.28 \\
Corn tamale & Ures & 12.45 & 1.69 \\
Cooked cheese & Ures & 15.00 & 0.56 \\
Corn tamale & Ures & 9.23 & 4.84 \\
Flour tortilla & Baviacora & 36.56 & 12.54 \\
Homemade bread & Baviacora & 50.68 & 14.65 \\
Chiltepin sauce & Aconchi & 49.43 & 4.93 \\
Big flour tortilla & Arizpe & 43.5 & 14.65 \\
Chiltepin sauce & Arizpe & 24.92 & 5.63 \\
Big flour tortilla & Bacanuchi & 62.04 & 11.55 \\
Flour tortilla & Bacanuchi & 53.24 & 10.99 \\
Cooked cheese & Bacanuchi & 17.4 & 42.68 \\
\hline
\end{tabular}

exposure routes must be explored in order to calculate a more precise HQ for additional metal contribution.

We did not include other metal exposure routes for the calculations of HQ, and some of the analyzed foods consumed by our study population had significant levels of arsenic and mercury. This represents a direction for future study.

\section{Conclusion}

This work showed that the mining activity performed in the Sonora River basin affects the groundwater quality. Coupled with this, reports of mining spills, especially August, 2014 spill, have highlighted the presence of arsenic and mercury in the aquifers. Despite the relatively low concentrations of arsenic and mercury from the analyzed samples, children are more vulnerable to this kind of pollutants and an important percentage of the participants are at risk of developing any one of a variety of chronic diseases related to arsenic and mercury exposure. To our knowledge, this is the first research conducted in this mining area which assesses the health risk of As and $\mathrm{Hg}$ exposure in children via drinking water. Our recommendation is to establish periodic drinking water monitoring in the area, and include other important exposures routes such as soil, dust and food, in order to evaluate the impact of mining activity in the population's health lon- 
gitudinally across time.

\section{Acknowledgements}

The authors would like to thank "Fideicomiso Rio Sonora" No. 80724, for its economic support, at the National Laboratory of Geology and Mineralogy (LANGEM), the children who participated in this study and all of whom worked in the sample collection, analysis, and data processing. This publication was financed with ITSON-PROFAPI_2018_0072 resources. Special thanks to Dr. Paul W. Kilpatrick for his support with the English edition.

\section{Conflicts of Interest}

The authors declare no conflicts of interest regarding the publication of this paper.

\section{References}

Adjei-Kyereme, Y., Donkor, A. K., Golow, A. A., Yeboah, P. O., \& Pwamang, J. (2015). Mercury Concentrations in Water and Sediment in Rivers Impacted by Artisanal Gold Mining in the Asutifi District, Ghana. Research Journal of Chemical \& Environmental Sciences, 3, 40-48.

Argos, M., Tara, K., Rathouz, P., Chen, Y., Pierce, B., Parvez, F., Islam, T., Ahmed, A., Rakibuz-Zaman, M., Hasan, R., Sarwar, G., Slavcovich, V., Van Geen, A., Graziano, J., \& Ahsan, H. (2010). Arsenic Exposure from Drinking Water, and All-Cause Chronic-Disease Mortalities in Bangladesh (HEALS): A Prospective Cohort Study. The Lancet, 376, 252-258. https://doi.org/10.1016/S0140-6736(10)60481-3

Babayan, G., Sakoyan, G., \& Sahakyan, G. (2017). Assessing the Quality of Water from Surface Sources of Drinking Water Supply to Towns of South Armenia. Electronic Journal of Natural Science, 1, 3-9.

Burgess, J. L., Kurzius-Spencer, M., O’Rourke, M. K., Littau, S. R., Roberge, J., Meza-Montenegro, M. M., Gutiérrez-Millán, L. E., \& Harris, R. B. (2013). Environmental Arsenic Exposure and Serum Matrix Metalloproteinase-9. Journal of Exposure Science \& Environmental Epidemiology, 23, 163-169. https://doi.org/10.1038/jes.2012.107

Buschmann, J., Berg, M., Stengel, C., \& Sampson, M. (2007). Arsenic and Manganese Contamination on Drinking Water Resources in Cambodia: Coincidence of Risk Areas with Low Relief Topography. Environmental Science \& Technology, 41, 2146-2152. https://doi.org/10.1021/es062056k

Castilhos, Z., Rodrigues-Filho, S., Villas Bôas, R., de Jesus, I., Lima, M., Faial, K., Miranda, A., Brabo, E., Beinhoff, C., \& Santos, E. (2015). Human Exposure and Risk Assessment Associated with Mercury Contamination in Artisanal Gold Mining Areas in Brazilian Amazon. Environmental Science and Pollution Research, 22, 11255-11264. https://doi.org/10.1007/s11356-015-4340-y

Chakraborti, D., Rahman, M., Murill, M., Das, R., Siddayya Patil, S., Sarkar, A., Dadapeer, H., Yendigeri, R., \& Das, K. (2013). Environmental Arsenic Contamination and Its Health Effects in a Historic Gold Mining Area of the Mangaluru Greenstone Belt of the Northeastern Karnataka, India. Journal of Hazardous Materials, 262, 1048-1055. https://doi.org/10.1016/j.jhazmat.2012.10.002

Chen, C., Chen, C., Wu, M., \& Kuo, T. (1992). Cancer Potential in Liver, Lung, Bladder and Kidney Due to Ingest Inorganic Arsenic in Drinking Water. British Journal of 
Cancer, 66, 888-892. https://doi.org/10.1038/bjc.1992.380

Chun, R., Hsu, K., Chen, C., \& Froines, J. (2000). Arsenic Methylation Capacity and Skin Cancer. Cancer Epidemiology, Biomarkers \& Prevention, 9, 1259-1262.

De Miguel, E., Clavijo, D., Ortega, M., \& Gómez, A. (2014). Probabilistic Meta-Analysis of Risk the Exposure to $\mathrm{Hg}$ in Artisanal Gold Mining Communities in Colombia. Chemosphere, 108, 183-189. https://doi.org/10.1016/j.chemosphere.2014.01.035

Del Águila, P., Martinez, M., \& Regalado, F. (2017). Cobre: Evoluciónreciente y potencial de desarrollo. Moneda Comodities, 171, 29-32.

http://www.bcrp.gob.pe/docs/Publicaciones/Revista-Moneda/moneda-171/moneda-17 1-05.pdf

Eke, D., \& Celik, A. (2008). Genotoxicity of Thimerosal in Cultured Human Lymphocytes with and without Metabolic Activation Sister Chromatid Exchange Analysis Proliferation Index and Mitotic Index. Toxicology in Vitro, 22, 927-934.

https://doi.org/10.1016/j.tiv.2008.01.012

Fato (2015). Brasil: Una tragedia historica, minas Gerais a 20 dias del derrame minero. La Via Campesina Movimiento Campesino Internacional.

https://viacampesina.org/es/brasil-una-tragedia-historica-minas-gerais-a-20-dias-del-d errame-minero/

Gleekia, A., Pradhan, D., \& Sahu, H. (2016). Impacts of Iron Ore Mining on Water Quality and the Environment in Liberia. In 6th Asian Mining Congress (pp. 371-380). Kolkata, India: The Mining Geological and Metallurgical Institute of India (MGMI).

Gomez-Parra, A., Forja, J., Delvalls, T., \& Riba, I. (2000). Early Contamination by Heavy Metals of the Guadalquivir Estuary after the Aznacóllar Mining Spill (SW Spain). Marine Pollution Bulletin, 40, 1115-1123. https://doi.org/10.1016/S0025-326X(00)00065-5

González-Merizalde, M. V., Menezes-Filho, J. A., Cruz-Erazo, C. T., Bermeo-Flores, S. A., Sánchez Castillo, M. O., Hernández-Bonilla, D., \& Mora, A. (2016). Manganese and Mercury Levels in Water, Sediment and Children Living near Gold-Mining Areas of the Nangaritzarivern Basin, Ecuadorian Amazon. Archives of Environmental Contamination and Toxicology, 71, 171-182. https://doi.org/10.1007/s00244-016-0285-5

Grandjean, P. (2007). Methylmercury Toxicity and Functional Programming. Reproductive Toxicology, 23, 414-423. https://doi.org/10.1016/j.reprotox.2007.03.002

Grandjean, P., Murata, K., Budtz-Jorgensen, E., \& Weihe, P. (2004). Cardiac Autonomic Activity in Methylmercury Neurotoxicity: 14-Year Follow-Up of a Faroese Birth Cohort. The Journal of Pediatrics, 144, 169-176.

https://doi.org/10.1016/j.jpeds.2003.10.058

Higueras, P., Oyarzun, R., Oyarzun, J., Maturana, H., Lillo, J., \& Morata, D. (2004). Environmental Assessment of Copper-Gold-Mercury Mining in the Andacollo and Punitaquidistrics, Northern Chile. Applied Geochemistry, 19, 1885-1864.

https://doi.org/10.1016/j.apgeochem.2004.04.001

INEGI Instituto Nacional de Estatistica y Geografía (2010). http://www.beta.inegi.org.mx/app/areasgeograficas/?ag=26

Jin-Soo, L., Hyo-Teak, C., \& Kyoung-Woong, K. (2005). Human Risk Assessment of As, $\mathrm{Cd}, \mathrm{Cu}$ and $\mathrm{Zn}$ in Abandoned Metal Mine Site. Environmental Geochemistry and Health, 27, 185-191. https://doi.org/10.1007/s10653-005-0131-6

Kwon, J., Nejad, Z., \& Jung, M. (2016). Arsenic and Heavy Metal in Paddy Soil and Polished Rice Contaminated by Mining Activities in Korea. CATENA, 148, 92-100. https://doi.org/10.1016/j.catena.2016.01.005

Mahamady, P., \& Orhan, G. (2016). Environmental Impacts of Gold Mining in Essakane 
Site of Burkina Faso. Human and Ecological Risk Assessment: An International Journal, 23, 641-654. https://doi.org/10.1080/10807039.2016.1263930

Malm, O. (1998). Gold Mining as a Source of Mercury Exposure in the Brazilian Amazon. Environmental Research, 77, 73-78. https://doi.org/10.1006/enrs.1998.3828

Martinez-Acuña, M. I., Mercado-Reyes, M., Alegría-Torres, J. A., \& Mejía-Saavedra, J. J. (2016). Preliminary Human Health Risk Assessment of Arsenic and Fluoride in Tap Water from Zacatecas, México. Environmental Monitoring and Assessment, 188, 476. https://doi.org/10.1007/s10661-016-5453-6

MCH Mineria Chilena (2016). Polémicaporreapertura de mineraBarrik Gold, trasderrame de cianuroen Argentina. Digital Magazine Mineria Chilena.

http://www.mch.cl/2016/10/05/polemica-reapertura-minera-barrick-gold-tras-derrame -cianuro-argentina

Muhammad, S., Shah, M., \& Khan, S. (2010). Arsenic Health Risk Assessment in Drinking Water and Source Apportionment Using Multivariate Statistical Techniques in Kohistan Region, Northern Pakistan. Food and Chemical Toxicology, 48, 2855-2684. https://doi.org/10.1016/j.fct.2010.07.018

Murata, K., Weihe, P., Budtz-Jorgensen, E., Jorgensen, P., \& Grandjean, P. (2004). Delayed Brainstem Auditory Evoked Potential Latencies in 14-Year-Old Children Exposed to Methylmercury. The Journal of Pediatrics, 144, 177-183.

https://doi.org/10.1016/j.jpeds.2003.10.059

Mwesigye, A., \& Tumwebaze, S. (2017). Water Contamination with Heavy Metals and Trace Elements from Kilambe Copper Mine and Tailing Sites in Western Uganda; Implications for Domestic Water. Chemosphere, 169, 281-287.

https://doi.org/10.1016/j.chemosphere.2016.11.077

NMX-AA-051-SCFI-2001 Análisis de Agua-Determinación de metals por absorción atomic en aguas naturales, potables, residuales y residualestratadas-Método de prueba.

Norma Oficial Mexicana, NOM-127-SSA1-1994 "Salud ambiental, agua para uso y consumo humano-límites permisibles de calidad y tratamientos a que debe someterse el agua para su potabilización”.

O’Rourke, M. K., Rogan, S. P., Jin, S., \& Robertson, G. L. (1999). Spatial Distributions of Arsenic and Mining Communities from NHEXAS Arizona. Journal of Exposure Analysis and Environmental Epidemiology, 9, 446-455.

https://doi.org/10.1038/sj.jea.7500050

Oribi, S., Dodoo, D., Armah, F., Essumag, D., \& Cobbina, J. (2010). Evaluation of Lead and Mercury Neurotoxic Health Risk by Resident Children in the Obuasi Municipality, Ghana. Environmental Toxicology and Pharmacology, 29, 209-212.

https://doi.org/10.1016/j.etap.2010.01.001

Phan, K., Sthiannopkao, S., Kim, K.-W., Wong, M. H., Sao, V., Hashim, J. H., Yasin, M. S. M., \& Aljunid, S. M (2010). Health Risk Assessment of Inorganic Arsenic Intake of Cambodia Residents through Groundwater Drinking Pathway. Water Research, 44, 5777-5788. https://doi.org/10.1016/j.watres.2010.06.021

Polanco, A., López, I., Casillas, A., Araujo, L., Prusty, A., \& Álvarez, F. (2017). Levels of Persistent Organic Pollution in Breast Milk of Maya Women in Yucatán, México. Environmental Monitoring and Assessment, 189, 1-13.

https://doi.org/10.1007/s10661-017-5768-y

Qian, Y., Chen, C., Zhang, Q., Li, Y., Chen, Z., \& Li, M. (2010). Concentrations of Cadmium, Lead, Mercury and Arsenic in Chinese Market Milled Rice and Associated Population Health Risk. Food Control, 21, 1757-1763.

https://doi.org/10.1016/j.foodcont.2010.08.005 
Razo, I., Carrizales, L., Castro, J., Diaz-Barriga, F., \& Monroyn, M. (2004). Arsenic and Heavy Metal Pollution of Soil, Water and Sediments in a Semi-Arid Climate Mining Area in México. Water, Air, \& Soil Pollution, 159, 129-152. https://doi.org/10.1023/B:WATE.0000015350.14520.c1

Robles, E., Tamara, L., Chavez, L., Falconi, V., Cartajena, J., Chumpitazi, J., \& Tamayo, R. (2012). Derrameminero de AntaminaenCajacay: A casiunmes, el valor de la saluden debate. Patio de Sociales.

Schutzmeier, P., Berger, U., \& Bose-O’Reilly, S. (2016). Gold Mining in Ecuador: A Cross-Sectional Assessment of Mercury in Urine and Medical Syntoms in Miners from Portovelo/Zaruma. International Journal of Environmental Research and Public Health, 14, 34. https://doi.org/10.3390/ijerph14010034

SEMARNAT Secretariadel Medio Ambiente y Recursos Naturales (2014). Fideicomiso Rio Sonora. http://www.fideicomisoriosonora.gob.mx

SGM Servicio Geológico Mexicano (2014). https://www.gob.mx/sgm

Sly, P., \& Porcenzuk, J. (2007). Guest Editorial: Susceptibility of Children to Pollutants. Paediatric Respiratory Reviews, 8, 273-274. https://doi.org/10.1016/j.prrv.2007.07.011

Smith, A., Goycolea, M., Haque, R., \& Lou, M. (1998). Marked Increase in Bladder and Lung Cancer Mortality in Region of Northern Chile Due Arsenic in Drinking Water. American Journal of Epidemiology, 147, 660-669. https://doi.org/10.1093/oxfordjournals.aje.a009507

Sohel, N., Persson, L., Rahman, M., Streatfield, P., Yunus, M., Ekström, E. C., \& Vather, M. (2009). Arsenic in Drinking Water and Adult Mortality. A Population Based Cohort Study in Rural Bangladesh. Epidemilogy, 20, 824-830. https://doi.org/10.1097/EDE.0b013e3181bb56ec

Steckling, N., Devleesschawer, B., Winkelnkemper, J., Fischer, F., Ericson, B., Kramer, A., Homberg, C., Fuller, R., Plass, D., \& Bose-O’Reilly, S. (2017). Supplementary Materials: Disability Weights for Chronic Mercury Intoxications Resulting from Gold Mining Activities: Results from an Online Pairwise Comparisons Survey. International Journal of Environmental Research and Public Health, 14, 57. https://doi.org/10.3390/ijerph14010057

Thurston, S., Bovet, P., Myers, G., Davidson, P., Georger, L., Shamlaye, C., \& Clarkson, T. (2007). Does Prenatal Methylmercury Exposure from Fish Consumption Affect Blood Pressure in Childhood? Neurotoxicology, 28, 924-930.

https://doi.org/10.1016/j.neuro.2007.06.002

Trejo-Acevedo, A., Díaz-Barriga, F., Carrizales, L., Domínguez, G., Costilla, R., Ize-Lema, I., Yarto-Ramirez M., Gavilán-García A., Saavedra-Mejía, J., \& Pérez-Maldonado, I. (2009). Exposure Assessment of Persistent Organic Pollutants and Metals in Mexican Children. Chemosphere, 74, 974-980.

https://doi.org/10.1016/j.chemosphere.2008.10.030

US-EPA (1992). Framework for Ecological Risk Assessment (366 p.). EPA-630/R-92/001, Washington DC: Environmental Protection Agency.

USEPA (2008). Child-Specific Exposure Factors Handbook. Washington DC: Office of Research and Development.

USEPA (2013). Regional Screening Levels (RSL) for Chemical Contaminants at Superfund Sites. Washington DC: USEPA.

Wongsasuluk, P., Chotpantarat, S., Siriwong, W., \& Robson, M. (2014). Heavy Metal Contamination and Health Risk Assessment in Drinking Water from Shallow Water Wells in an Agricultural Area in Ubon Ratchathani Province, Thailand. Environmental 
Geochemistry and Health, 36, 169-182. https://doi.org/10.1007/s10653-013-9537-8

Yasuda, M., Yustiawati, Suhaemi, M., Tajuddin, M., Hosokawa, T., Sait, T., Tanaka, S., \& Kurasaki, M. (2011). Metal Concentration of River Water and Sediments in West Java, Indonesia. Bulletin of Environmental Contamination and Toxicology, 87, 669-673. https://doi.org/10.1007/s00128-011-0411-z

Zhou, H., Zeng, M., Zhou, X., Liao, B. H., Liu, J., Lel, M., Zhong, Q. Y., \& Zheng, H. (2013). Assessment of Heavy Metal Contamination and Bioaccumulation in Soybean Plants form Mining and Smelting Areas of Southern Hunan Province, China. Environmental Toxicology and Chemistry, 32, 2719-2727. https://doi.org/10.1002/etc.2389

Zulling, K., \& Hendryx, M. (2011). Health-Related Quality of Life among Central Appalachian Residents in Mountaintop Mining Counties. American Journal of Public Health, 101, 848-853. https://doi.org/10.2105/AJPH.2010.300073 